\title{
Stabilization of Soil: A Review
}

\author{
Santosh Dhakar ${ }^{1}$, S.K. Jain ${ }^{2}$ \\ ${ }^{1}$ M.E. Student \\ ${ }^{2}$ Professor
}

\begin{abstract}
If good earth is not available at the construction site, it becomes imperative to opt for soil stabilization. Soil stabilization is a process to treat a soil to maintain or improve the performance of the soil as a construction material. The stabilizing agent improves the strength parameters of sub grade of road pavement and leads to strengthening of embankment. The objective of this paper is to review the applications of different stabilizing agents such as lime, fly ash, cement, rice husk, expanded polystyrene geofoam and waste paper sludge for different type of soil.
\end{abstract}

Keywords: Fly ash, Lime, Cement, Expanded polystyrene (EPS) Geofoam, Waste paper sludge

\section{Introduction}

General: The soil which contains the silt and clay particles show considerable sign of distress accompanied by loss of strength of the soil during rainy seasons and shrinkage during summer. Black cotton soil is one such type of soil which loses its strength during rainy season due to their expansive behavior. The problems of expansive behavior of soil are as follows (N.B.O. 1962).

a. Expansive soils have high plasticity and compressible when they are saturated.

b. These types of soil have high strength in dry state, becomes soft after saturation. Filling up water into fissures and cracks, accentuates the process of softening causing reduction of shear strength and leading to low bearing capacity.

c. Structure built in a dry season show differential heaving as a result of swelling of soils during subsequent wet season. Restriction on swelling causes swelling pressure, making the structure unstable. This causes structure supported on soils to lift up with the development of cracks.

d. Structure built at the end of wet season when the natural water content is high show shrinkage crack and settlement, during dry season. Shrinking cause a downward thrust on the foundation through skin friction thus increasing the foundation load.

Due to these reasons expansive soils need treatment prior to use as an engineering material. These treatments are generally classified into two process, viz. (1) soil modification and (2) soil stabilization.

Soil stabilization is the process of blending and mixing materials with a soil to improve certain properties of the soil. The process may include the blending of soils to commercially available admixtures that may alter the gradation, texture or plasticity, or act as a binder for cementation of the soil (IRC:SP:89-2010).

Soil modification is the stabilization process in which improvement in some property of the soil but does not result in a significant increase in soil strength and durability (IRC:SP:89-2010).
Soil properties like strength, compressibility, workability, swelling potential and volume change tendencies may be altered by various soil stabilization and modification methods.

Stabilization is derived by thermal, mechanical, chemical or electrical means. Thermal and electrical is rarely used and less data is available about these two. Mechanical stabilization or compaction is the densification of soil by the use of mechanical energy. By the densification air is expelled from the soil voids without much change in moisture content. This method is used to stabilize cohesionless soils where compaction energy can cause rearrangement and interlocking of particles. But, the techniques are not effective if the soil is subjected to significant moisture fluctuation. The efficiency of compaction may also diminish with an increase of fine content, fraction smaller than 75 micron, of the soil. This is because inter particle bonding andrearrangement during compaction. Changing the physio-chemical properties of fine grained soil by chemical stabilization is a more effective form of durable stabilization then densification. Chemical stabilization of non cohesive, coarse grained soil with greater than $50 \%$ by weight coarser than 75 micron is also profitable if a substantial stabilization reaction achieved in the soil (Dallas and Syam, 2009).

\section{Quality improvement due to stabilization}

By the stabilization better soil gradation, increase in durability, increase in strength, reduction of plasticity index and reduction in swelling potential is achieved. Stabilization improves the properties of construction materials and gives the following attributes (IRC:SP:89-2010).

a) After saturation with water substantial proportion of their strength is retained.

b) Resistance to erosion.

c) Surface deflection is reduced.

d) The elastic moduli of layers constructed above stabilized layer are increased.

e) The stiffness and strength of a soil layer can be increased through the use of admixture to reduce the thickness of the road pavement. 


\section{International Journal of Science and Research (IJSR)}

ISSN (Online): 2319-7064

Index Copernicus Value (2013): 6.14 | Impact Factor (2015): 6.391

\section{Possible Problems due to Stabilization}

The stabilization of soil also causes the following problems (IRC:SP:89-2010).

(a) Due to thermal and shrinkage cracks stabilized layer may be crack.

(b) Crack can reflect through the surfacing and allow water to enter the pavement.

(c) If $\mathrm{CO}_{2}$ has access to the material, the stabilization reaction is reversible and the strength of layer can decrease.

(d) The construction operation requires more skill than unstabilize materials

\section{Materials}

\section{a) Fly Ash}

Fly ash itself has less cementitious value but it reacts chemically and form cementitious compound in presence of moisture. Cementitious compound formed improves the strength and compressibility of soil (Karthik et al., 2014).

Karthik et al., (2014) evaluated the effect of fly ash derived from combustion of sub-bituminous coal at electric power plants, for stabilization of soft fine grained red soil. The Liquid Limit, Plastic Limit and Specific gravity of soil was $32 \%, 23.37 \%$ and 2.7 respectively. Test was conducted on soil and soil-fly ash mixtures prepared at optimum water content of $9 \%$. At $6 \%$ of fly ash the bearing capacity of soil changes from $10 \mathrm{~kg} / \mathrm{mm}^{2}$ to $35 \mathrm{~kg} / \mathrm{mm}^{2}$ and $\mathrm{CBR}$ value changes from $3.1 \%$ to $4.82 \%$. Due to increase in CBR values the thickness of pavement decreases from 12 inches to 8.5 inches.

Ahmed (2014) stabilized the clayey soil for the construction of urban roads using fly ash. Author found that the optimum ratio of fly ash with clayey soil is $15 \%$ by weight of soil. A dramatic reduction in the properties of soil is seen for $0 \%$ to $15 \%$ of fly ash content but no noticeable decline appear in the range $15 \%$ to $20 \%$ of fly ash content. For compaction, the dry density and O.M.C were measured for various fly ash ratios. The dry density raise as the fly ash increases up to $15 \%$, then reduced to 1.53 at $20 \%$ of fly ash. The liquid limit decreased from $55 \%$ to $48 \%$ for increase of fly ash from $0 \%$ to $15 \%$ by weight. Plasticity Index changes from $30 \%$ to $13 \%$ for addition of $0 \%$ to $15 \%$ of fly ash. C.B.R value of soil changes from $3 \%$ to $56 \%$.

Gyanen et al., (2013) evaluates the compaction of stabilized black cotton soil using two type of fly ash, viz. (1) fine and (2) coarse. The natural black cotton soil was taken from Gadag district of Karnataka. The Liquid Limit, Plastic Limit, Natural water content and Specific gravity of soil were $66 \%$, $37.12 \%, 8.95 \%$ and 2.68. Fine fly ash soil has M.D.D $1.35 \mathrm{~g} / \mathrm{cc}$ for $95 \%$ of soil and $5 \%$ of fly ash. The M.D.D becomes $1.35 \mathrm{~g} / \mathrm{cc}$ for $95 \%$ soil and $5 \%$ fly ash mixture and lowest density was $0.6 \mathrm{~g} / \mathrm{cc}$ for $70 \%$ soil and $30 \%$ fly ash. The coarse fly ash has M.D.D $1.35 \mathrm{~g} / \mathrm{cc}$ for $95 \%$ soil and $5 \%$ fly ash mixture and lowest density about $1.0 \mathrm{~g} / \mathrm{cc}$ for $70 \%$ soil and $30 \%$ fly ash.

Ashish et al., (2013) stabilize the Black cotton soil found in Maharashtra using fly ash. The fly ash content was increased from 0 to $50 \%$. Soil under study has O.M.C. 20.4\%, M.D.D $14.7 \mathrm{~N} / \mathrm{m}^{3}$ C.B.R (Soaked) 3.1\%, CBR (Unsoaked) $6.89 \%$. Stabilization of soil was done at $0 \%, 10 \%, 20 \%, 30 \%$, $40 \%$ and $50 \%$ of fly ash content. O.M.C is maximum at $10 \%$ of fly ash, has $29.17 \%$. M.D.D. is maximum at $20 \%$ fly ash, has $14.97 \mathrm{~N} / \mathrm{m}^{3}$. Soaked CBR is $2.52 \%$ for $10 \%$ fly ash and unsoaked C.B.R. is $22.90 \%$ for $20 \%$ fly ash.

Bhuvaneshwari et al., (2005) studied the effect of fly ash on soil. Authors increase the fly ash content from 0 to $50 \%$. The soil has Liquid Limit 30\%, Plastic Limit 18\%, Plasticity Index $12 \%$, Dry Density $18.04 \mathrm{KN} / \mathrm{m}^{3}$ and Unconfined compressive strength $2697 \mathrm{KN} / \mathrm{m}^{2}$. The Dry Density was continuously decreases and $15.13 \mathrm{KN} / \mathrm{m}^{3}$ at $50 \%$ of fly ash. Unconfined compressive strength is also decreases and becomes $1176 \mathrm{KN} / \mathrm{m}^{2}$ for $50 \%$ of fly ash.

Brooks (2009) stabilized expansive soil of CH type. Author uses Fly ash and Rice Husk ash (RHA) to stabilize the soil. O.M.C and M.D.D of untreated soil is $20 \%$ and $15.5 \mathrm{kN} / \mathrm{m}^{3}$ respectively. In stress strain graph of unconfined compressive strength it is clearly shown that failure stress and strain increased by $106 \%$ and $50 \%$ respectively when the fly ash content was increased from 0 to $25 \%$. When the RHA content was increased from 0 to $12 \%$, unconfined compressive stress increased by $97 \%$ while CBA improved by $47 \%$. Author concluded that $12 \%$ of RHA and $25 \%$ of fly ash is used for strengthening the expansive sub grade soil. Based on laboratory test $15 \%$ of fly ash was mixed with RHA to form a swell reduction layer.

Anil Kumar and Sudhanshu (2014) stabilize the expansive soil using fly ash and Rice Husk ash. Soil was collected from village Sukkha, District Jabalpur Madhya Pradesh. Soil has $8 \%$ sand and $92 \%$ silt + clay. The Liquid limits, Plastic limit, C.B.R, O.M.C, MDD $\left(\mathrm{kN} / \mathrm{m}^{3}\right)$ and free swell Index of soil is $53 \%, 30 \%, 1.5-2 \%, 26 \%, 1.52 \%$ and $35 \%$ respectively. In his study author comes to the conclusion that Liquid Limit is decreases to $55 \%$ for $20 \% \mathrm{FA}+25 \%$ RHA, plasticity Index is decreases to $86 \%$ for $20 \% \mathrm{FA}+25 \%$ RHA, Differential free swell is decreases to $75 \%$ for $15 \%$ $\mathrm{FA}+20 \%$ RHA and specific gravity changes from 2.61 to 2.20 .

Dilip Shrivastava et al., (2014) used the soil of Bilhari area of Jabalpur (M.P.). Soil has specific gravity 2.56, Liquid limit $48.5 \%$, Plastic limit $22.7 \%$, Plasticity Index $25.8 \%$, shrinkage limit $8.61 \%$. Authors made a series of laboratory experiments on $5 \%$ lime mixed with $5 \%, 10 \%, 15 \%$ and $20 \%$ of RHA by weight of dry soil. The CBR value is increased by $287.62 \%$ and unconfined compressive strength is improved by $30 \%$. The Differential free swell index is decreased by $86.92 \%$ with increase of RHA form 10 to $20 \%$.

Yadu and Tripathi (2013) stabilized the soft soil, collected from Tatibandh-Atari, rural road of Raipur Chhattisgarh, by the use of Granulated blast furnace slag and fly ash. The soil was classified as CI-MI as per Indian standard classification system. Different amount of GBS, i.e. 3, 6 and $9 \%$ with different amount of fly ash i.e. 3\%, 6\%, 9\% and 12\% were used to stabilize the soil. Based on compaction and C.B.R test, authors concluded that the optimum amount of GBS with fly ash was a $3 \%$ fly ash and $6 \%$ GBS.

\section{Volume 5 Issue 6, June 2016} www.ijsr.net 


\section{International Journal of Science and Research (IJSR) \\ ISSN (Online): 2319-7064 \\ Index Copernicus Value (2013): 6.14 | Impact Factor (2015): 6.391}

Raut et al., (2014) stabilized the clayey soil collected from nearby of Yeshwantro College of engineering, Wanadongri Nagpur. In his study murrum of Kalmeshwar quarry and fly ash of Koradi power plant near Nagpur is used. The clayey soil has Gravel $1 \%$, sand $20 \%$, silt $28 \%$, and clay $51 \%$. Based on these properties soil is classified as $\mathrm{CH}$. Specific gravity, Liquid limit, plastic limit, plasticity Index, M.D.D and O.M.C of soil is $2.55,52 \%, 20.80 \%, 30.50 \%, 16.88 \%$ and $19.0 \%$ respectively. Authors stabilized the soil by fly ash and murrum. With increase in content of fly ash and murrum UCS and M.D.D. increases up to certain proportion and then decreases. Maximum value of UCS and M.D.D, found at $7.5 \%$ of murrum and $5 \%$ of fly ash, was $4.95 \mathrm{gm} / \mathrm{cm}^{3}$ and $0.328 \mathrm{gm} / \mathrm{cm}^{2}$.

Singh and Pani (2014) used Lime and fly ash as a stabilization material for Highway. Author evaluated the C.B.R values for both soaked and un-soaked condition, O.M.C, M.D.D of compacted fly ash mixed with $1 \%, 2 \%$, $5 \%$ and $10 \%$ lime. After the work they come to the result that dry unit weight changes from 1.142 to $1.255 \mathrm{KJ} / \mathrm{m}^{3}$, and O.M.C decreases from 30.2 to $24.2 \%$. With addition of lime M.D.D increases and OMC decreases. Addition of lime results in filling the voids of compacted fly ash thus increased the density. The maximumun soaked and soaked CBR valuess $25.39 \%$ and $1.546 \%$ respectively.

\section{b) Lime Stabilization}

Reaction of lime with soil is grouped into two parts, viz (i) Initial and (ii) Long term. The initial reaction involved flocculation and ion exchange. Longer term reactions involve reaction between the soil particle and free lime. These reactions are pozzolanic because they involved pozzolans. These pozzolanic reaction occur when free lime reacts with water as a result cementing effect is occur between soil and lime. The increase in strength of soil is depending on the degree of pozzolonic reaction between lime and soil (Dallas and Syam, 2009).

Wu Li (2010) uses lime as stabilization material to stabilize the Tanzania soil. Author uses three types of soil moderately plastic silty clay, moderately plastic tan clay and Heavy clay with $5 \%$ of hydrated Lime. Author designated them as N-11, $\mathrm{N}-12$ and $\mathrm{N}-13$ respectively. Plasticity Index decreases form $25 \%$ to $4 \%$ for $\mathrm{N}-11,29 \%$ to $6 \%$ for $\mathrm{N}-12$ and 36 to $9 \%$ for $\mathrm{N}-13$. Unconfined compressive strength changes from 145 to $2770 \mathrm{KPa}$ for $\mathrm{N}-11,280$ to $3000 \mathrm{KPa}$ for $\mathrm{N}-12$ and 163 to $2200 \mathrm{KPa}$ for $\mathrm{N}-13$. Resilient modulus changes from $79 \mathrm{MPa}$ to $275 \mathrm{MPa}$ for $\mathrm{N}-11,53 \mathrm{MPA}$ to $63 \mathrm{MPA}$ for $\mathrm{N}-12$ and 35.8MPA to 209MPA for N-13.

Olugbenga et al., (2011) stabilized the Lateritic soil by the use of lime. Lateritic soil form a group comprising a wide variety of Yellow, brown, red, fine grained residual soil of light texture. They are characterized by the presence of iron and aluminum oxide or hydroxide which gives the colour to the soil. In this paper author studied the suitability and lime stabilization requirement of lateritic soil samples. Soil samples A, B, C collected from a dam site and stabilized with $0 \%, 2 \%, 4 \%, 6 \%, 8 \%$ and $10 \%$ of lime. Optimum lime content for the samples A, B, C were $8 \%, 6 \%, 6 \%$ respectively. Plasticity Indices is reduced as the lime increases. The C.B.R of sample 'A' increased from 10.6\% at
$0 \%$ to $29.0 \%$ at $8 \%$ lime, while that of ' $\mathrm{C}$ ' improved from $2.5 \%$ to $8.6 \%$ at $6 \%$. The compressive and shear strength were also improved. The uncured compressive strength of ' $\mathrm{B}$ ' improved from $119.13 \mathrm{KN} / \mathrm{m}^{2}$ at $0 \%$ to $462.81 \mathrm{KN} / \mathrm{m}^{2}$ at $6 \%$ lime. Author concluded that sample $\mathrm{A}$ and $\mathrm{B}$ will be suitable as base material while sample ' $\mathrm{C}$ ' will be suitable as sub grade material.

Malhotra and John, describes the use of mechanical equipment in the construction of four stretches of lime stabilized roads extending over a length of twenty kilometer. He selected four roads of Amraoti circle in Maharastra, viz. (1) Amraoti Asra road, (2) Asra Mana road, (3) Daryapur Amla road, (4) Achaopur Kakda road. All the four roads were B.C soil of $\mathrm{CH}$ group. In his study authors stabilized the B.C soil by $2 \%$ of lime and their service behavior was observed. For a period of four year, stabilized sections behaved very satisfactorily but thereafter, the lime treated stretches started deterioration.

Ankur et al., (2014) stabilize the Black cotton soil using Lime and stone dust. For his study, Black cotton soil sample were collected from Gwalior-Jhansi road (M.P) and stone dust was collected from Aman Vihar Industrial area, New Delhi. The Black cotton soil had specific gravity 2.61, percentage passing Is sieve 75 micron is $58.0 \%$, liquid limit $57 \%$, plastic limit $31.4 \%$, plasticity index $26.5 \%$, differential free swell $41.0 \%$, M.D.D $16.1 \mathrm{KN} / \mathrm{m}^{3}$, CBR (soaked) $1.50 \%$ and unconfined compressive strength $166.2 \mathrm{KN} / \mathrm{m}^{2}$. Author classified soil as $\mathrm{CH}$ according to the unified soil classification system. In their study, authors determine optimum percentage of lime was $9 \%$ and stone dust was mixed by $5 \%, 10 \%, 15 \%, 20 \%$ and $25 \%$ by weight of limeblack cotton soil. The MDD of lime stabilized B.C. soil increases up to the addition of $20 \%$ stone dust and further increase of the stone dust decreases the value. Similarly for CBR and UCS the strength increases up to $20 \%$ addition of stone dust in lime stabilized soil.

\section{c) Cement Stabilization}

Cement can be used to stabilize any soil except highly organic soils (IRC:SP:89-2010). Numbers of reactions occur when cement is added to the clayey soil. These reactions are flocculation, ion exchange, carbonation and pozzolanic reactions (Rawas et al., 2005). Due to these reactions property of soil like strength and durability improved.

Oyediran and Kalejaiye (2011) studied the effect of increasing of cement by weight on the strength and compaction parameter of lateritic soil of south west Nigeria. Three soil samples were collected from pit at depths of $0.5 \mathrm{~m}, 1.0 \mathrm{~m}$ and $2.0 \mathrm{~m}$. The soil was stabilized with $2 \%, 4 \%$, $8 \%, 10 \%$, and $20 \%$ by weight of cement. The average of properties of soil collected from pit are as follows; Specific gravity 2.60, Liquid Limit 40.91\%, plastic limit $23.59 \%$, plasticity Index $17.31 \%$, gravel $8.33 \%$, sand $52.33 \%$, silt $18.00 \%$, clay $21.33 \%$ and amount of fineness $39.33 \%$. M.D.D, C.B.R and UCS of soil increased while there is reduction in O.M.C as cement was increases. But addition of more than $10 \%$ by weight of cement decreased M.D.D, UCS and C.B.R and increase in the O.M.C. Author concluded that the increasing in percentage of cement was not guarantee for the improvement of geotechnical properties. 


\section{International Journal of Science and Research (IJSR) \\ ISSN (Online): 2319-7064}

Index Copernicus Value (2013): 6.14 | Impact Factor (2015): 6.391

Zoubi (2008) stabilized expansive soil from Jordan by the use of cement. The natural soil has liquid limit of $53 \%$ and plasticity index of $26 \%$. According to the unified soil classification system, author classified the soil as inorganic clay of high plasticity $(\mathrm{CH})$. Cement content increased from $0 \%$ to $25 \%$. Author study showed that the liquid limit of soil decreases for cement content up to $6 \%$, then increased as the cement content increases from $6 \%$ to $10 \%$ after this the liquid limit becomes constant. The study also shows that swelling potential of soil decreases for cement content up to $4 \%$, then increased as the cement content increased from $4 \%$ to $6 \%$ after which the swelling potential may decrease or may becomes constant depending on the initial water content. The undrained shear strength increases with increase of cement content from $0 \%$ to $20 \%$. The maximum rate of increase in undrained shear strength was observed between 6 to $10 \%$ of cement content.

\section{d) Expanded polystyrene (EPS) Geofoam}

Shelke and Murty (2010) used EPS Geofoam to reduce the swelling pressure of expansive soil. Black cotton soil from Ahmednagar district in Maharastra was taken for study. According to USCS soil classification, soil has $\mathrm{CH}$ type. The Liquid limit, Plastic limit, plasticity index, O.M.C, M.D.D and free swell index of soil was $61 \%, 31 \%, 30 \%, 20 \%$, $16.2 \mathrm{KN} / \mathrm{m}^{3}$ and $85.7 \%$ respectively. In his study, authors used two type of geofoam, viz. (1) $6 \mathrm{~mm}$ thickness and (2) $12 \mathrm{~mm}$ thickness. Swelling of Black cotton soil reduces from $8.64 \%$ to $82.72 \%$ when EPS Geofom of $6 \mathrm{~mm}$ and $12 \mathrm{~mm}$ are used. Swelling pressure of $6 \mathrm{~mm}$ geofoam is reduced to $42.86 \%$ and for $12 \mathrm{~mm}$ thickness swelling pressure is reduced about $90 \%$.

\section{e) Waste Paper Sludge}

Waste paper sludge (WPS) is a waste material collected from the paper industry. Elias (2015) stabilized the soil using waste paper sludge. Soil used in the study was clayey soil from kannadikadaves kundannoor of Ernakulam district. Soil contains $74 \%$ silt , 26\% clay, having Liquid limit $60 \%$, plastic limit $31 \%$, shrinkage limit $23 \%$, plasticity index $30 \%$, specific gravity 2.59 M.D.D, $16.3 \mathrm{KN} / \mathrm{m}^{3}$, O.M.C $22 \%$, UCS $316.4 \mathrm{KN} / \mathrm{m}^{2}$ and cohesion $158.2 \mathrm{KN} / \mathrm{m}^{2}$. The waste paper sludge sample was collected in plastic container from the sludge drying bed of the Hindustan newsprint, Vellore, Kottayam. When soil treated with WPS M.D.D of soil was decreased and O.M.C was increased. The UCS for soil for varying percentage such as $2 \%, 4 \%, 5 \%, 6 \%, 7 \%$ and $10 \%$ of WPS increased to better strength. The addition of WPS increased the strength at 5\% and it was found to be constant and optimum value of strength to soil.

\section{References}

[1] IRC: SP: 89-2010,“Guidelines for Soil and Granular Material Stabilization Using Cement, Lime and Fly ash", Indian Road Congress, New Delhi.

[2] Karthik, S., Kumar, Ashok., Gowtham,P., Elango,G., Gokul,D., Thangaraj,S. (2014), "Soil Stabilization by Using Fly ash", IOSR Journal of Civil and Mechanical Engineering, IOSR-JMCE, Vol. 10, pp 20-26.

[3] Ahmed, Afaf Ghais Abadi (2014), "Fly ash Utilization in Soil Stabilization", International Conference on Civil,
Biological and Environmental Engineering, CBEE, pp 76-78.

[4] Gyanen, Takhelmayum., Savitha, A.L.,Krishna, Gudi.(2013), "Laboratory Study on Soil Stabilization Using Fly ash Mixtures ", International Journal of Civil Engineering Science and Innovative Technology, vol. 2, pp 477-481.

[5] Mehta, Ashish., Parate, Kanak.,Ruprai,B. S. (2013), "Stabilization of Black Cotton Soil by Fly ash", International Journal of Application or Innovative in Engineering and Management.

[6] Bhuvaneshwari, S., Robinson, R.G., Gandhi, S. R. (2005), "Stabilization of Expansive Soils Using Fly ash", Fly Ash Utilization Programme , FAUP, TIFAC, DST, Vol. 8, pp 5.1-5.9.

[7] Robert M, Brooks. (2009), "Soil Stabilization with Fly ash and Rice Husk Ash", International Journal of Research and Reviews in Applied Sciences, Vol. 1, pp 209-217.

[8] Singhal,Anil kumar and Singh,Sudhanshu shekhar (2014), "Laboratory Study on Soil Stabilization Using Fly ash and Rice Husk Ash", International Journal of Research in Engineering and Technology, Vol. 3, pp 348-351.

[9] Shrivastava,Dilip., Singhai, A. k. and Yadav, R. K (2014), "Effect of Lime and Rice Husk Ash on Engineering Properties of Black Cotton Soil" . International Journal of Engineering Research and Science Technology, Volume 3.

[10] Yadu, Laxmikant and Tripathi, R. K (2013), "Stabilization of Soft Soil with Granulated Blast Furnance Slag and Fly ash", International Journal of Research in Engineering and Technology, vol. 2, pp 115-119.

[11] Raut, J. M., Bajad, S.P., Khadeshwar. S. R (2014), "Stabilization of Expansive Soil Using Fly ash and Murrum", International Journal Innovative Research in Science, Engineering and Technology, vol. 3, pp 1428014284.

[12] Singh, S. P andPani, A (2014), "Evaluation of Lime Stabilized Fly ash as a Highway Material" International Journal of Environmental Research and Development, Vol. 4, pp 281-286.

[13] Fikiri Fredrick Magafu, Wu Li (2010), "Utilization of Local Available Materials to Stabilize Native Soil (earth roads) in Tanzania-Case Study Ngara", SciRP, pp 516519.

[14] Olugbenga, Oludolapo Amu. , Oluwole, Fakunle Bamisay and Iyiole, Akanmu Komolafe (2010), "The Suitability and Lime Stabilization Requirement of Some Lateritic Soil Samples as Pavement", Int. J. Pure Appl. Sci. Technol., 2(1), PP 29-46.

[15] Malhotra. B. R and John. K. A, "Need for Construction Equipment in Rural Roads- A Case Study" Ministry of Rural Development, GOI, Government Of India.

[16] Mudhgal,Ankur., Sarkar,Raju andSahu, A. K(2014), "Effect of Lime and Stone Dust in the Geotechnical Properties of Black cotton soil” Int. J. of GEOMATE, Vol. 7,pp 1033-1039.

[17] Oyediran, I. A andKalejaiye, M (2011), "Effect of Increasing Cement Content on Strength and Compaction Parameters of Some Lateritic Soil from South Western Nigeria”, EJGE, Vol. 16,pp 1501-1513. 


\section{International Journal of Science and Research (IJSR) \\ ISSN (Online): 2319-7064}

Index Copernicus Value (2013): 6.14 | Impact Factor (2015): 6.391

[18] Al-zoubi, Mohammed Shukri (2008), "Undrained Shear Strength and Swelling Characteristic of Cement Treated Soil", Jordan Journal of Civil Engineering, Vol. 2,pp 53-61.

[19] Shelke, A.P and Murty, D.S (2010), "Reduction of Swelling Pressure of Expansive Soils Using EPS Geofoam" Indian Geotechnical Conference, GEO trendz.

[20] Neva Elias(2015), "Strength Development of Soft Soil Stabilize with Waste Paper Sludge", International Journal of Advanced Technology in Engineering and Science, Vol. 3,pp 141-149.

[21]N.B.O (1962). "N.B.O 15- First Report On Building Foundation in Shrinkable Soil (Second Edition)", National Buildings Organization, Ministry of works, Housing \& Supply, Govt. of India, New Delhi.

Volume 5 Issue 6, June 2016 www.ijsr.net 